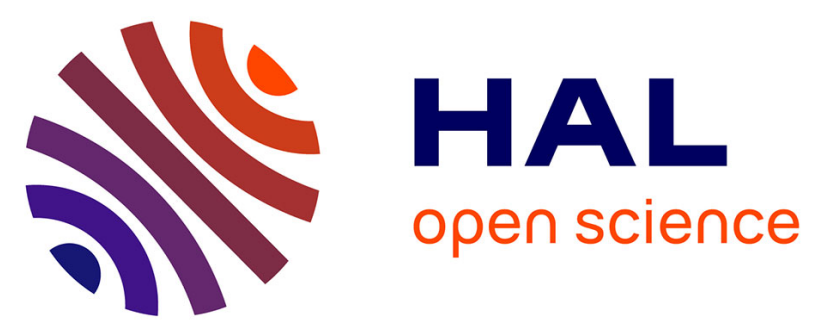

\title{
Global climate change and local watershed management as potential drivers of salinity variation in a tropical coastal lagoon (Laguna de Terminos, Mexico)
}

Renaud Fichez, D. Archundia, Christian Grenz, Pascal Douillet, Francisco Gutierrez Mendieta, Montserrat Origel Moreno, Lionel Denis, Adolfo Contreras Ruiz Esparza, Jorge Zavala-Hidalgo

\section{To cite this version:}

Renaud Fichez, D. Archundia, Christian Grenz, Pascal Douillet, Francisco Gutierrez Mendieta, et al.. Global climate change and local watershed management as potential drivers of salinity variation in a tropical coastal lagoon (Laguna de Terminos, Mexico). Aquatic Sciences - Research Across Boundaries, 2017, 79 (2), pp.219 - 230. 10.1007/s00027-016-0492-1 . hal-01780226

\section{HAL Id: hal-01780226 \\ https://hal-amu.archives-ouvertes.fr/hal-01780226}

Submitted on 27 Apr 2018

HAL is a multi-disciplinary open access archive for the deposit and dissemination of scientific research documents, whether they are published or not. The documents may come from teaching and research institutions in France or abroad, or from public or private research centers.
L'archive ouverte pluridisciplinaire HAL, est destinée au dépôt et à la diffusion de documents scientifiques de niveau recherche, publiés ou non, émanant des établissements d'enseignement et de recherche français ou étrangers, des laboratoires publics ou privés. 


\section{Aquatic Sciences}

\section{Global climate change and local watershed management as potential drivers of salinity variation in a tropical coastal lagoon (Laguna de Terminos, Mexico).

\author{
--Manuscript Draft--
}

\begin{tabular}{|c|c|}
\hline \multicolumn{2}{|l|}{ Manuscript Number: } \\
\hline Full Title: & $\begin{array}{l}\text { Global climate change and local watershed management as potential drivers of salinity } \\
\text { variation in a tropical coastal lagoon (Laguna de Terminos, Mexico). }\end{array}$ \\
\hline Keywords: & $\begin{array}{l}\text { Tropical; lagoon; watershed; salinity; climate change; ENSO; river discharge; land } \\
\text { use; environmental management; sustainable development. }\end{array}$ \\
\hline \multicolumn{2}{|l|}{$\begin{array}{l}\text { Corresponding Author Secondary } \\
\text { Information: }\end{array}$} \\
\hline First Author: & Renaud Fichez, Ph.D. \\
\hline \multicolumn{2}{|l|}{ First Author Secondary Information: } \\
\hline \multirow[t]{5}{*}{ Order of Authors: } & Renaud Fichez, Ph.D. \\
\hline & Denisse Archundia, MSc \\
\hline & Christian Grenz, PhD \\
\hline & Pascal Douillet, PhD \\
\hline & Francisco Gutiérrez Mendieta, PhD \\
\hline
\end{tabular}

Order of Authors Secondary Information:

\begin{tabular}{ll} 
Abstract: & $\begin{array}{l}\text { The wide range of ecological goods and services provided by tropical coastal lagoons } \\
\text { and wetlands are under considerable pressure due to the synergistic effects of local } \\
\text { anthropogenic impact and global climate change. Salinity is an essential ecological } \\
\text { driver which depends on the balance between marine and estuarine inputs, and the } \\
\text { ongoing decline in fisheries recruitment in the Gulf of Mexico has been linked to } \\
\text { environmental degradation of coastal ecosystems, among which long-term changes in } \\
\text { salinity is a potential key factor. As part of a joint study of the wide and shallow coastal } \\
\text { lagoon of Terminos in south eastern Mexico, we established that salinity variability was } \\
\text { directly related to river discharge variability. Minimum discharge from the Usumacinta } \\
\text { River and its tributary the Palizada River during the wet season of } 2009 \text { maintained led } \\
\text { to very unusually high salinity in the lagoon. Data collected over the past } 60 \text { years } \\
\text { revealed a sustained long-term increase in river flow rates in the Usumacinta } \\
\text { watershed, even though precipitation rates during the same period were constant. This } \\
\text { indicates that the increase in river flow rates may be attributable to anthropogenic } \\
\text { alteration of the watershed rather than to a long-term impact of climate change. The } \\
\text { 2009 positive salinity anomaly was further related to an El Niño Modoki episode. } \\
\text { Through the study of potential short- to long-term interactions between salinity, river } \\
\text { discharges, precipitation and El Nino-La Nina oscillations, we reached conclusions that } \\
\text { should be of great value to environmental management and sustainable development. }\end{array}$ \\
\hline
\end{tabular}




\section{Suggested Reviewers:}

James Cloern, PhD

Senior scientist, United States Geological Survey, Menlo Park, USA

jecloern@usgs.gov

Dr. James Cloern is a renowned senior research scientist working on comparative ecology and biogeochemistry of estuaries to understand how they respond as ecosystems to climatic-hydrologic variability and human disturbance

Carlos Gay-García, PhD

Centro de Ciencias de la Atmósfera, Universidad Nacional Autónoma de México, México D.F., Mexico cgay@unam.mx

Dr. Carlos Gay García is the top climate change specialist in Mexico and will be able to assess the local to global dimension of the presented work. However, is position in the same research center as 2 co-authors could present a potential conflict of interest 
Global climate change and local watershed management as potential drivers of salinity variation in a tropical coastal lagoon (Laguna de Terminos, Mexico).

Renaud Fichez ${ }^{1}$, Denisse Archundia ${ }^{2}$, Christian Grenz ${ }^{1}$, Pascal Douillet ${ }^{1}$, Francisco Gutiérrez Mendieta $^{3}$, Montserrat Origel Moreno ${ }^{1,3}$, Lionel Denis ${ }^{4}$, Adolfo Contreras Ruiz Esparza $^{5}$, Jorge Zavala-Hidalgo ${ }^{5}$

1. Aix Marseille Université, CNRS/INSU, Université de Toulon, IRD, Mediterranean Institute of Oceanography (MIO) UM 110, 13288, Marseille, France

2. CNRS, INP, IRD, Université Joseph Fourier, Laboratoire d'étude des Transferts en Hydrologie et Environnement (LTHE) UM 5564, Grenoble, France

3. Universidad Autónoma Metropolitana-Iztapalapa, Departamento de Hidrobiología, México D.F., Mexico

4. Université des Sciences et Technologies de Lille, Laboratoire d'Océanologie et de Géosciences (LOG) UM 8187, Wimereux, France

5. Universidad Nacional Autónoma de México, Centro de Ciencias de la Atmósfera, México

D.F.,

Mexico 


\begin{abstract}
The wide range of ecological goods and services provided by tropical coastal lagoons and wetlands are under considerable pressure due to the synergistic effects of local anthropogenic impact and global climate change. Salinity is an essential ecological driver which depends on the balance between marine and estuarine inputs, and the ongoing decline in fisheries recruitment in the Gulf of Mexico has been linked to environmental degradation of coastal ecosystems, among which long-term changes in salinity is a potential key factor. As part of a joint study of the wide and shallow coastal lagoon of Terminos in south eastern Mexico, we established that salinity variability was directly related to river discharge variability. Minimum discharge from the Usumacinta River and its tributary the Palizada River during the wet season of 2009 maintained led to very unusually high salinity in the lagoon. Data collected over the past 60 years revealed a sustained long-term increase in river flow rates in the Usumacinta watershed, even though precipitation rates during the same period were constant. This indicates that the increase in river flow rates may be attributable to anthropogenic alteration of the watershed rather than to a long-term impact of climate change. The 2009 positive salinity anomaly was further related to an El Niño Modoki episode. Through the study of potential short- to long-term interactions between salinity, river discharges, precipitation and El Nino-La Nina oscillations, we reached conclusions that should be of great value to environmental management and sustainable development.
\end{abstract}




\section{Introduction}

Tropical coastal lagoons and wetlands are highly productive ecosystems providing numerous ecological goods and services essential to sustainable development (Moberg and Rönnbäck 2003). In coastal systems, changes in freshwater regime and water quality directly impact community composition, ecosystem functioning and living resources (Sale et al. 2014; Putland et al. 2014). As is the case for most tropical coastal lagoons, Terminos Lagoon has been the subject of few studies, yet it was singled out as a pilot site in the framework of the Gulf of Mexico Large Marine Ecosystem Program (GoM-LME) from the Global Environment Facility (GEF), and as the focus of the Joint Environmental Study of Terminos Lagoon (JEST) program, aimed at reinforcing our understanding of environmental processes in shallow tropical lagoons. Salinity gradients, substrates ranging from silt and clay to calcareous sands, and specific habitats such as seagrass beds and mangroves all strongly contribute to the presence of highly complex communities in terms of diversity, distribution, abundance and trophic status (Yáñez-Arancibia et al. 1983; Grenz et al. 2015). As a consequence, Terminos Lagoon is considered to be an essential area for breeding and juvenile development of the commercial species encountered on the continental shelf of Campeche Sound. Catches in that area account for one-third of the Mexican fish market captured in the Gulf of Mexico and the Caribbean Sea, but have experienced a significant collapse since the early 1980s (Robadue et al. 2005; Fichez 2013). Shrimp for example, are one of the most valuable living resources in the Gulf and rely strongly on coastal lagoons to complete their reproductive cycle, yet this fishery has experienced drastic decline largely due to continually decreasing recruitment (Arreguin-Sanchez 2008). Based on the subsequent need for biodiversity conservation and economic resource protection, Terminos Lagoon and the surrounding wetlands stretching over a total area of 705,016 hectares currently form the largest RAMSAR site in Mexico (Mitsch and Hernandez 2013). 
In such a critical ecosystem, recent concern has arisen that an increase in salinity related to climate change might be building up, detrimentally impacting juvenile developmental stages of exploited species (Ramos Miranda et al. 2005a; 2005b; Sosa Lopez et al. 2005; Villéger et al. 2010). Those authors observed a loss in functional diversity and a biotic homogenization in the fish community of Terminos Lagoon which they linked to a salinity increase between the years 1980-1981 and 1998-1999, and interpreted as a regular shift from hypohaline to euhaline/hyperhaline status due to climate change (Ramos Miranda et al. 2005a).

Concurrent with this scenario, recent catastrophic flooding events have occurred in the Tabasco and Chiapas Mexican states, resulting in economic - and more dramatically - human losses (Aparicio et al. 2009). Such events are commonly and hastily attributed to climate change, especially by political leaders for whom invoking the planetary dimension of global change is often a way to disclaim any direct responsibility. The truth is that most climate change studies predict periods of lower precipitation for the Gulf Coast region and Central America (Biasutti et al. 2012). Barcena et al. (2010) did not anticipate significant precipitation change during the first half of the $21^{\text {st }}$ century, but expected precipitation to decline by $7 \%$ in Guatemala, by $10 \%$ in Belize under the IPCC emission scenario B2 and by around $30 \%$ in Belize and Guatemala of scenario A2 during the second half of the $21^{\text {st }}$ century. Significant reductions in precipitation (by as much as 5-10\%) and runoff (by as much as 10-30\%) in northern Central America have been predicted for the 2050-2099 period using the IPCC A1B emission scenario (Hidalgo et al. 2013). But decreasing precipitation is also expected to be accompanied by an increase in hydrological variability, reinforcing extreme events of flooding and drought. Even though population exposure to water stress will increase substantially with climate change, climate prediction uncertainties at the regional to local scale are still considered as large (Met Office 2011), rendering the establishment of efficient long-term management policies difficult. Beyond its inherent scientific interest, the present study follows a logical, linear course from salinity variability to river inputs and precipitation rates, and thus provides valuable scientific information that may be of significant help in 
isolating key issues at stake in immediate decision-making in terms of sustainable environmental management.

\section{Material and methods}

\subsection{Study site}

Terminos Lagoon, located inland on the southern coast of the Gulf of Mexico in the Mexican state of Campeche (Fig. 1a), stands between two very distinct geologic provinces with specific hydrological regimes. To the east stretches the Yucatan Peninsula, characterized by low rainfall and a porous calcareous basement resulting in the absence of proper river catchment, with rainfall penetrating directly through the carbonate basement, thus supplying the groundwater cap which discharges as diffusive non-point sources all along the Gulf of Mexico and Caribbean Sea coasts. To the west and south lie the lowlands of Tabasco and the highlands of Chiapas and Guatemala, the latter of which receives heavy tropical rainfall. Four rivers, of which two combine to form a single estuary, reach Terminos Lagoon (Robadue et al. 2004) delivering an average yearly volume of $11.9610^{9} \mathrm{~m}^{3} \mathrm{yr}^{-1}$ of freshwater, corresponding to roughly 2.6 times the lagoon volume. In comparison, the subtraction of

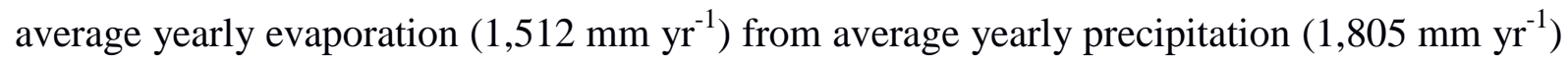
(David and Kjerfve 1998; Espinal et al. 2007) yielded a yearly net rainfall contribution of $293 \mathrm{~mm} \mathrm{yr}^{-1}$, whereas groundwater contribution accounted for $410^{6} \mathrm{~m}^{3} \mathrm{yr}^{-1}$ (David 1999). Total annual net freshwater input to Terminos Lagoon was thus estimated at $12.5710^{9} \mathrm{~m}^{3} \mathrm{yr}^{-1}$, of which river discharge, precipitation net input, and groundwater seepage accounted for $95.44 \%, 4.53 \%$ and $0.03 \%$, respectively, with river discharge therefore being by far the most significant source of freshwater inputs to Terminos Lagoon.

The Chumpán River reaches Terminos Lagoon through Balchacah Lagoon delivering an average annual freshwater discharge of $0.610^{9} \mathrm{~m}^{3} \mathrm{yr}^{-1}$. The Candelaria River, with an average annual flow rate of $2.110^{9} \mathrm{~m}^{3} \mathrm{yr}^{-1}$, converges with the small Mamantel River system which drains only $0.1610^{9} \mathrm{~m}^{3} \mathrm{yr}^{-1}$, to form the Candelaria-Panlau system that connects to the south- 
eastern part of Terminos Lagoon through the Pargos estuary. Finally, the Palizada River, with an average annual discharge of $9.110^{9} \mathrm{~m}^{3} \mathrm{yr}^{-1}$, reaches Terminos Lagoon through the El

Vapor, El Este and Del Viento lagoons and the San Francisco and Chica openings, and accounts for more than two-thirds of the river input to Terminos Lagoon. Beyond its own small river catchment, the Palizada is a tributary of the Usumacinta River, which in turn relates to the intertwined Grijalva-Usumacinta basins that stretch over a total area of 112,550 $\mathrm{km}^{2}$ (Hudson et al. 2005). Receiving an average annual rainfall of $1,709 \mathrm{~mm} \mathrm{yr}^{-1}$, the Usumacinta River discharges an average annual freshwater volume of $6910^{9} \mathrm{~m}^{3} \mathrm{yr}^{-1}$ to the Gulf of Mexico. Slightly less than one-tenth of this flow is delivered through the Palizada River into Terminos Lagoon, with the remaining nine-tenths merging with the Grijalva River catchment to reach the open sea directly through the Grijalva-Usumacinta Estuary.

Including its tributary lagoons, Terminos Lagoon (Fig. 1b) stretches over a surface of $1,936 \mathrm{~km}^{2}$ with an average depth of only $2.4 \mathrm{~m}$, corresponding to a total water volume of $4.65 \mathrm{~km}^{3}$ (Contreras Ruiz Esparza et al. 2014). The lagoon is connected to the sea by two inlets: 'Carmen Inlet' on the western side (4 km long) and 'Puerto Real Inlet' on the eastern side ( $3.3 \mathrm{~km}$ long). The two inlets are separated by Carmen Island, a carbonated sandbar 30 $\mathrm{km}$ long and $2.5 \mathrm{~km}$ wide. The shallow system is disrupted only by 2 deep channels respectively located on the eastern part of each inlet and through which strong currents alternate as a function of the tidal cycle of inflow and outflow.

Climate varies between the tropical wet and dry category in the lowlands and the tropical rainforest category in the highlands. There are three distinct seasonal periods throughout the year: the relatively dry period from February to May and the rainy period from June to September are separated by a period of northern gales called "Nortes".

\subsection{Data collection and analysis}

Salinity data with a precision of 0.001 were obtained from vertical profiles conducted with a SeaBird (C SBE 19 CTD over a network of 34 stations (Fig. 1b) and a total of 12 sampling trips covering the 2-year period from October 2008 to November 2010, with a more intensive 
sampling effort during 2010 (7 sampling trips). Data acquisition frequency was $0.25 \mathrm{sec}$ and only downward profiles at a velocity of circa $0.5 \mathrm{~m} \mathrm{sec}^{-1}$ were retained for data analysis. The

SeaBird (C SBE 19 CTD was calibrated by the manufacturer on a yearly basis.

Daily river flow rates were obtained from the Mexican Comisión Nacional de Agua (CONAGUA) hydrological surveys database, available from the website (http://www.conagua.gob.mx/CONAGUA07/Contenido/Documentos/Portada\%20BANDAS. htm). Long-term records of daily river flow rates were available for the 1995-2011 period for the Mamantel River, for the 1992-2011 period for the Palizada River, for the 1953-2011 period for the Candelaria River, and for the 1948-2011 period for the Usumacinta River (Bocca del Cerro hydrological station, upstream Terminos Lagoon). Given the quality of each data series and the dominance of Palizada River inputs to Terminos Lagoon, our study focused on the data series from the Palizada and Bocca del Cerro stations. Daily rainfall at Bocca del Cerro station corresponding to river flow rate time series were obtained from the Servicio Meteorológico Nacional database, also managed by CONAGUA and accessible through the Centro de Investigación Científica y de Educación Superior de Ensenada (CICESE) website "Base de datos climatologica nacional - Sistema CLICOM" (http://clicom-

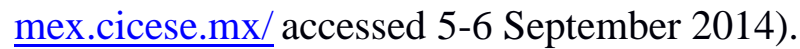

Average salinity between 0 and $75 \mathrm{~cm}$ depth was spatially interpolated using UNIRAS A/S software to generate 2D distribution maps. However, the lagoon size imposed sampling over several days (4 to 6), potentially rendering such asynchronous sampling strategy sensitive to short term variability. Salinity variations in the lagoon are essentially driven by variations in i) tidal exchanges with the Gulf of Mexico, ii) internal lagoon hydrodynamics (tide accounting for $65 \%$ of current variability (David and Kjerfve 1998), iii) precipitation versus evaporation budgets, and iv) river inputs. With limited exchange taking place through two shallow and narrow inlets and with average tidal amplitude of only $0.3 \mathrm{~m}$, tidally driven salinity variations between two sampling points can be considered as negligible at the scale of a tidal cycle or 
even at the scale of a few days (Contreras Ruiz Esparza et al. 2014). River discharge, precipitation, wind regime and daily temperature cycles were constant over each sampling

period as well as during the previous five days, so the results can be considered as being representative of a stable situation. Finally, it must be acknowledged that, all driving factors combined, water residence time in this $1,936 \mathrm{~km}^{2}$ system ranges from one to five months (Robadue et al. 2004), which significantly limits daily variability in salinity at the sampling grid scale.

Linear regression was used to assess relationships between data as well as trends in time series. In addition, the seasonal Mann-Kendall test (Hirsch and Slack 1984) was used as it constitutes a well-fitted nonparametric method to statistically assess monotonic trends in hydrological long-term time series that are generally asymmetrically distributed (Machiwal and Jha 2008).

\section{Results}

\subsection{Salinity}

Due to its nature as a semi-enclosed lagoon subject to significant freshwater inputs, salinity in Terminos Lagoon was strongly variable at the spatial as well as the temporal scale, as shown by the temporal survey of salinity distribution from October 2008 to November 2010 (Fig. 2). Changes in salinity distribution during 2010 gave an overview of the general variability pattern of the system over a full yearly cycle. As a consequence of the dry season, salinity values averaged over the whole lagoon increased from (mean \pm SD) $29.3 \pm 4.3$ in January to $33.0 \pm 3.0$ in May. At this time, salinity maximum values in the range of 33 to 37 over the whole lagoon approached open sea salinity values, which were in the range of 36 to 38 (Thacker 2007). This increase in salinity coincided with the progressive disappearance of brackish plumes from the Candelaria and Palizada Rivers in the eastern and western inshore parts of the lagoon. During the following rainy period, salinity values averaged over the 
whole lagoon decreased progressively to $16.41 \pm 4.87$ (mean \pm SD) reaching one-digit values in the most inshore areas, while at the same time, values over 20 were measured close to

Puerto Real Inlet and leeward of Carmen Island only. The observed progressive decrease in salinity corresponded to the progressive extension of Candelaria and Palizada brackish plumes within the lagoon.

Comparison of salinity distribution for corresponding periods of 2008, 2009 and 2010 revealed that a strong positive anomaly occurred during the wet season of 2009. Salinity distributions in March 2009 and March 2010 were strongly similar, with average values $($ mean $\pm S D)$ of $32.41 \pm 3.35$ and $31.29 \pm 3.36$, respectively. In 2009 , salinity remained high in September and October, at $34.45 \pm 1.96$ and $32.64 \pm 4.34$, respectively, and decreased only slightly in December to $28.12 \pm 3.62$. In comparison, lagoon-wide average salinity in October 2008, September 2010 and November 2010 was significantly lower at $13.70 \pm 5.65$, $17.00 \pm 5.40$ and $16.41 \pm 4.87$, respectively. Whereas salinity distributions in October 2008 and in September and November 2010 can be considered as representative of the peak of the wet season with minimum values of salinity in most parts of the lagoon, the situation observed in 2009 during the same period stands out as a strong positive anomaly to the usual seasonal cycle.

Evidence for such a salinity anomaly during the wet season of 2009 was further sustained by comparison with data from previous works (Yañez Arancibia et al. 1983; Ramos Miranda et al. 2005a). Even though the networks of 18 (Yañez Arancibia et al. 1983) and 24 stations (Ramos Miranda et al. 2005a) sampled during those previous studies was not as dense as the one used during the JEST program, the distribution of sampling points from the three studies can be considered as being representative of the spatial variability in the lagoon. The general convergence of values between yearly cycles from 2010 (present work) and 1980 (YañezArancibia et al. 1983) (Fig. 3) confirmed the existence of a significant decrease in salinity in Terminos Lagoon during the September to November period, and therefore highlighted the 
presence of unusually high salinity during the same period in 2009. Additionally, Ramos Miranda et al. (2005a) reported average \pm SD salinity values for periods of four months in the range of $20.0 \pm 9.8$ during the October 1997 to January 1998 period, $27.7 \pm 6.3$ during the February to May 1998 period, and $31.0 \pm 5.9$ during the June to September 1998 period. This led them to underline the convergence with the seasonality in hydroclimatic patterns recorded by Yañez-Arancibia et al. (1983).

\subsection{River flow rate anomaly}

Given the previously established predominance of river discharge over other sources of fresh water input to the lagoon, it was necessary to analyze historical records of river flow rates in order to assess the potential relationship with salinity. In September 2009, monthly discharge in the Palizada River reached a maximum of $224 \mathrm{~m}^{3} \mathrm{~s}^{-1}$, by far the lowest value for the post wet season yearly maximum derived for the 1992-2011 period (average $458 \mathrm{~m}^{3} \mathrm{~s}^{-1}$ ). The salinity anomaly observed during 2009 in Terminos Lagoon can thus be related to a historical minimum discharge from Palizada River. Analysis of the relationship between Palizada River inputs and Terminos Lagoon salinity during the 2008-2010 sampling period (Fig. 4) established a reasonably tight linear relationship $\left(\mathrm{R}^{2}=0.7\right)$ which confirms the major impact of river discharge on Terminos Lagoon salinity. This further raised the issue of a possible longterm relationship between climate change, river flow rates, and salinity in Terminos Lagoon, with potential consequences in terms of environmental status alteration.

Regarding long-term trends in river flow rates, it is commonly assumed that acceptable climatic variability assessments require data records in excess of 30 years with few or no multi-year gaps (Hanson et al. 2004). The CONAGUA Palizada database covered only a 19 year period, insufficient to support climatic trend analysis. However, the Palizada River is merely a short tributary in the extensive Usumacinta River watershed, for which much longer recordings of river flow rates were available. The linear regression between monthly river flow rates from the Palizada and Usumacinta Rivers (from the upstream hydrological station 
of Boca del Cerro ) yielded a 1 to 11 ratio $\left(\mathrm{R}^{2}=0.77\right)$, a ratio in close agreement with previous studies (Robadue et al. 2004). Using data from Boca del Cerro station to investigate long-term

trends in river discharge in the watershed upstream of Terminos Lagoon was further justified because synchronous long-term series of river flow rates and rainfall are available dating back to 1948 .

The 1948 to 2011 survey of Usumacinta River monthly flow rates at Boca del Cerro station (Fig. 5a) followed a typical yearly pattern identical to that from Palizada River, showing minimum and maximum discharges during the April-June and September-November period, respectively, and recording the 2009 wet season discharge as the lowest of the whole time series. The linear regression supported visual analysis in favor of a temporal increase in river discharge even though the strong yearly variability described above yielded a low $\mathrm{R}^{2}$. The seasonal Mann Kendall nonparametric test yielded a score of 4,242 and a p-value of $1.310^{-12}$, confirming the occurrence of a statistically significant positive trend. From the linear regression equation it was possible to calculate average monthly flow rate as increasing from $1,699 \mathrm{~m}^{3} \mathrm{~s}^{-1}$ in 1948 to $2,157 \mathrm{~m}^{3} \mathrm{~s}^{-1}$ in 2011 .

Long-term records of precipitation over the same 1948-2011 period at Boca del Cerro station (Fig. 5b) yielded an average monthly precipitation rate of $192 \mathrm{~mm}$ with a wide range of variation, from no rainfall at all to a maximum of $661 \mathrm{~mm}$ in September 1966. Rainfall variability was thus stronger than variability of monthly average river discharge, and so logically contributed to an even lower $\mathrm{R}^{2}$. In spite of this, the linear regression yielded a slope equivalent to zero, attesting to the absence of long-term change in precipitation rates. This pattern of stability was confirmed statistically by the Man-Kendall test, which did not reject the "no trend" null hypothesis. The stable trend in precipitation rates over the 64-year period thus strongly contrasted with the observed increase in river discharge over the same period of time at the Bocca del Cerro station on the Usumacinta River. 


\subsection{ENSO relationship}

The potential relationship between climate change and the combined occurrence of local anomalies in salinity and river discharge had to be assessed. The Oceanic Niño Index (ONI: http://www.cpc.ncep.noaa.gov/products/analysis_monitoring/ensostuff/ensoyears.shtml) rose to the 0.5 threshold value in the June-August period of 2009 and up to a maximum of 1.6 in the November-January and December-February 2009-2010 periods, before decreasing below the 0.5 threshold value during the April-June period of 2010 and rapidly entering a 10- month La Niña event beginning in the June-August period. Even though 2009 appeared as the most drastic year in terms of low river discharge, it was far from the most severe El Niño event of the past 60 years, so the long-term relationship between the El Niño index and Usumacinta River discharge needed further analysis to assess the general pertinence of a potential cause and effect relationship.

In order to test this hypothesis, we crossed the NOAA Oceanic Niño Index against monthly averaged river flow rates at Boca del Cerro station using various time shifts. The best correlation was obtained with a two-month lag between the ONI central month and monthly averaged river flow rates (Figure 6), but that relationship still was very weak. Even strong El Niño or La Niña events could not systemically be related to decreases or increases in river discharge, respectively.

\section{Discussion}

Salinity variation in time and space was high in Terminos Lagoon, ranging from one digit values (estuarine) to 36 (marine), with spatial gradients shifting strongly as a function of the balance between marine and freshwater inputs. A low salinity plume generally spread north of Palizada Estuary toward Carmen Inlet along the western part of the lagoon. Considering their respective freshwater discharges, the Candelaria-Panlau system and the Chumpan River clearly had a much lower impact on salinity distribution in the lagoon. Salinities of up to 3336, thus fairly close to salinities of the Gulf of Mexico marine waters (Thacker 2007), were 
always measured close to the Puerto Real Inlet and leeward of Carmen Island, confirming that marine waters enter through Puerto Real Inlet during flooding and are transported westward

along the coast of Carmen Island (Graham et al. 1981; Kjerfve 1988; David and Kjerfve 1998; Contreras Ruiz Esparza et al. 2014). Inter-annual comparison based on data from 2009 and 2010 and from previous studies (Yañez Arancibia et al. 1983; Ramos Miranda et al. 1985a) revealed the presence of a strong positive salinity anomaly during the wet season of 2009 . This was an exceptional situation for which environmental drivers had to be identified, logically starting with river inputs.

After establishing the tight relationship between river flow rates in the Usumacinta River and its tributary, the Palizada River, the long term analysis of Usumacinta River discharge revealed a long-term increase instead of the climate change-related decrease in river flow rate anticipated from previous studies (Ramos Miranda et al. 2005a; Sosa Lopez et al. 2005). A key issue, both in terms of scientific inquiry and of environmental management, was to understand the reasons for such a long-term change and, in particular, to assess whether it is related to changes in climatic conditions and/or to poor practices in local watershed management. No significant historical change in precipitation rates was observed at Boca del Cerro hydrological station, a trend consistent with climate modeling approaches which generally predict undetectable changes at the beginning of the $21^{\text {st }}$ century, followed by a decrease in precipitation (Barcena et al. 2010, Sáenz-Romero et al. 2010, Met Office 2011, Biasutti et al. 2012, Hidalgo et al. 2013). Despite that long term rainfall stability, Usumacinta River discharge regularly increased during the past 60 years therefore excluding climate change as a driver of the long-term historical increase in Usumacinta River discharge and, instead, lending support to the hypothesis of a local impact. Deforestation to expand agricultural and ranching lands has been consistently linked to increased rainwater runoff resulting in higher river discharges. This relationship is locally supported by previous work on satellite image analysis. Soto-Galera et al. (2010) evidenced changes from original land cover in more than half of the Terminos Lagoon area during the period from 1974 to 2001, and 
revealed that $31 \%$ of the area occupied by mature vegetation in 1974 had been degraded by 2001: tropical forest and mangroves presented the most extensive coverage losses, while urban areas and grassland for livestock farming increased considerably. Net mangrove surface loss was 17,426 ha in Campeche between 1970 and 2005, corresponding to an $8 \%$ loss from the initial mangrove surface area (Valderrama et al. 2014). At a larger scale, during the 1976 to 2009 period, the watersheds surrounding Terminos Lagoon were the most affected by deforestation of all the watersheds of Mexico: the Grijalva-Usumacinta, Mamantel and Candelaria basins lost $20-30 \%, 30-50 \%$ and $<10 \%$ of their primary vegetation, respectively. Furthermore, all three basins lost 30-50\% of their secondary vegetation (Cotler Ávalos, 2010). Additionally, a comparable increase in river discharge unrelated to precipitation and linked to deforestation and expansion of the agricultural and ranching land was reported from the Candelaria watershed (Benitez et al. 2005). In such a context, and considering the tight relationship between the Usumacinta River and the Palizada River, the ongoing long-term trend in Terminos Lagoon is more likely to be one of salinity decrease rather than increase.

We also observed the coincidental occurrence of (i) a low yearly maximum river discharge, (ii) a positive salinity anomaly in Terminos Lagoon and (iii) a moderately severe El Niño event during the period from July 2009 to April 2010 which was immediately followed by a La Niña event from July 2010 to April 2011. However, only a weak correlation could be evidenced between Usumacinta River flow rates and the ENSO ONI index during the past 60 years. Studies relating ENSO with rainfall in Mexico similarly identified a noticeable but very weak correlation (Pavia et al. 2006; Bravo Cabrera et al. 2010), with precipitation decreasing southward and increasing northward under "El Niño" conditions and inversely under "La Niña" conditions. The same studies also predicted significant decreases in wet season precipitation rates, leading to severe drought events such as the one observed in 2009. This relationship is of strong significance to coastal brackish ecosystems, as it has been demonstrated that river runoff amplifies changes in rainfall (Austin et al. 2010). However, ENSO accounted for only 3.7 to $8.9 \%$ of rainfall variance, due to the complexity of weather 
phenomena affecting precipitation, with correlations being mostly non-significant in the Usumacinta watershed area (Bravo Cabrera et al. 2010).

To close our comparison with the two available sets of historical salinity data in Terminos Lagoon, it must be stressed that 1980 (data from Yañez-Arancibia et al. 1983) corresponded to a so-called normal climatic year, whereas the October 1997 to September 1998 period (data from Ramos Miranda et al. 2005a) corresponded to a shift from El Niño (maximum ONI value of 2.4 in November 1997) to La Niña (minimum ONI value of -1.2 in September 1998) conditions. Despite weak evidence of a relationship between ENSO and river discharge, the increase in average salinity observed by Ramos Miranda et al. (2005a) in Terminos Lagoon and that they interpreted as a long-term shift due to climate change may, instead, could be related to the occurrence of an El Niño event during the October 1997 to September 1998 period.

Additionally, it must be stressed that the 2009 ENSO event was classified as an ENSO Modoki. The effect of this rather new climatic factor cannot be fully assessed as yet, and will require clarification in future analyses of temporal data series (Ashok et al. 2007). A conventional El Niño event is characterized by strong anomalous warming in the eastern equatorial Pacific, whereas an El Niño Modoki is associated with strong anomalous warming in the central tropical Pacific and cooling in the eastern and western tropical Pacific. El Niño Modoki events seem to have different impacts than conventional El Niño events, and the suspected relationships with strong drought events in the south-eastern part of Mexico will require much more data gathering before proper assessments can be made.

\section{Conclusion}

The present study establishes that salinity in Terminos Lagoon depends on river inputs and that the occurrence of an exceptional river discharge minimum during the wet season of 2009 corresponded to a positive salinity anomaly. Over the long term, and despite future 
predictions of decreasing river discharge in the region, we observed a sustained increase in river flow rates in the Usumacinta River watershed during the past 60 years of available data, indicating that salinity in Terminos Lagoon decreased rather than increased during this 60 year period. Precipitation rates during the same period were constant, proving that the recorded past increase in river discharge resulted from unsustainable land use rather than climate change impact. Finally, no clear general relationship could be established between river flow rates and ENSO indexes such as the ONI, and this despite not only the coincidence between the 2009 ENSO event, but also the observed decrease in river flow rate and the positive salinity anomaly in Terminos Lagoon. These results should be of significant value to decision-makers who are often quick to point the finger at global climate change when, in fact, local environmental management is most likely involved. In the context of ongoing land use changes it is pertinent to keep sight of the fact that certain features of the natural environment help mitigate the negative consequences that arise from floods, both in terms of the economy and, more importantly, of population safety (Brody et al. 2012).

Additionally, environmental management has to be planned on a long-term scale and the context of predicted future changes urgently calls for gathering long-term information on key environmental variables, starting with basic drivers such as temperature and salinity. If a shift in rainfall is likely to occur as predicted by converging climate models, salinity in Terminos Lagoon will be directly impacted. For this reason, assessing future trends and their potential impacts on biodiversity and living resources within - as well as beyond - the limits of this critical ecosystem is essential. A major environmental protection site such as Terminos Lagoon should, at the least, have its own observation network surveying key environmental variables such as salinity on a long-term basis. Such a monitoring objective should even be extended to the Gulf of Mexico scale - if not to the national and regional scales - since environmental protection in the Mesoamerican region is not confined within the boundaries of national frontiers. The current lack of long-term information is detrimental both to the understanding of ecosystem equilibrium as well as to sustainable development in the context 
of the ongoing global change and its potential critical impact on the Gulf of Mexico and Caribbean region. 1 


\section{Acknowledgment}

This work was supported by the Institut de Recherche pour le Développement (IRD), the Centre National de la Recherche Scientifique (CNRS), the Universite de Lille, the Universidad Autónoma Metropolitana-Iztapalapa (UAM-I) and the French National Program Ecosphère Continentale et Côtière - Dynamique et Réactivité des Interfaces Littorales (EC2CO-DRIL). We are very thankful to the Instituto de Ciencias del Mar y Limnologia, Universidad Nacional Autónoma de México (ICML-UNAM) for providing access to their field station in Ciudad del Carmen. We are equally indebted to the Mexican Comisión Nacional del Agua (CONAGUA) for online access to long-term series of river discharges and precipitation through their databases "Banco Nacional de Datos de Aguas Superficiales" (BANDAS) and "Base de datos climatologica nacional - Sistema CLICOM", respectively. 


\section{Figure captions}

Fig. 1 (a) Main and detailed watersheds contributing to freshwater inputs to the Terminos Lagoon and (b) bathymetry of Terminos Lagoon with location of sampling stations.

Fig. 2 Distribution of salinity (0 to $75 \mathrm{~cm}$ surface layer average) in Terminos Lagoon from October 2008 to November 2010.

Fig. 3 Monthly evolution of salinity averaged over the whole Terminos Lagoon during 1980 (Yanez-Arancibia et al., 1983) and 2009-2010 (present study)

Fig. 4 Relationship between average salinity in Terminos Lagoon and corresponding monthly averaged Palizada River discharge from October 2008 to November 2010 with insertion of linear regression line, equation and determination coefficient (R2).

Fig. 5 (a) Monthly averaged Usumacinta River discharge and (b) monthly cumulative precipitation rates at Boca del Cerro station during the 1948-2011 period with insertion of linear regression line, equation and determination coefficient $\left(\mathrm{R}^{2}\right)$.

Fig. 6 Relationship between NOAA Oceanic Niño Index (ONI) and monthly averaged river flow rates at Bocca del Cerro station using a positive time shift of 2 months with insertion of linear regression line, equation and determination coefficient $\left(\mathrm{R}^{2}\right)$. 


\section{References}

Aparicio J, Martínez-Austria PF, Güitrón A, Ramírez AI (2009) Floods in Tabasco, Mexico: a diagnosis and proposal for courses of action. Journal of Flood Risk Management, 2:132138

Arreguin-Sanchez F, Zetina-Rejón M, Ramírez-Rodríguez M (2008) Exploring ecosystembased harvesting strategies to recover the collapsed pink shrimp (Farfantepenaeus duorarum) fishery in the southern Gulf of Mexico. Ecological Modelling, 214:83-94

Ashok K, Behera SK, Rao SA, Weng H, Yamagata T (2007) El Nino Modoki and its possible teleconnection. Journal of Geophysical Research - Oceans, 112:C11007

Austin J, Zhang L, Jones RN, Durack P, Dawes W, Hairsine P (2010) Climate change impact on water and salt balances: an assessment of the impact of climate change on catchment salt and water balances in the Murray-Darling Basin, Australia. Climatic Change, 100:607631

Barcena A, Prado A, Beteta H, Samaniego JL, Lennox J (2010) The Economics of Climate Change in Central America. UN-CEPAL report.

Benítez JA, Sanvicente Sánchez H, Lafragua Contreras J, Zamora Crescencio P, Morales Manilla LM, Mas Caussel JF, García Gil G, Couturier SA, Zetina Tapia R, Calan Yam RA, Amabilis Sánchez L, Acuña CI, Mejenes MC (2005) Sistema de información geográfica de la Cuenca del Río Candelaria: Reconstrucción histórica de los cambios en la cobertura forestall y su efecto sobre la hidrología y calidad del agua. In: Kauffer Michel EF (ed) El agua en la frontera México-Guatemala-Belice, Universidad Autónoma de Chiapas, Tuxtla Gutiérrez, México, pp.19-32

Biasutti M, Sobel AH, Camargo SJ, Creyts TT (2012) Projected changes in the physical climate of the Gulf Coast and Caribbean. Climatic Change, 112:819-845. 
Bravo Cabrera JL, Azpra Romero E, Zarraluqui Such V, Gay García C, Estrada Porrúa F (2010) Significance tests for the relationship between "El Niño" phenomenon and precipitation in Mexico. Geofísica Internacional, 49:245-261

Brody SD, Peacock WG, Gunn J (2012) Ecological indicators of flood risk along the Gulf of Mexico. Ecological indicators, 18:493-500

Contreras Ruiz Esparza A, Douillet P, Zavala-Hidalgo J (2014) Tidal dynamics of the Terminos lagoon, Mexico: observations and 3D numerical modelling. Ocean Dynamics, 64:1349-1371

Cotler Ávalos H., 2010, Las cuencas hidrograficas de México Diagnostico y Priorizacion. http://www2.inecc.gob.mx/publicaciones/consultaPublicacion.html?id_pub=639

David LT (1999) Laguna de Términos, Campeche. In: Smith SV, Marshall Crossland JI, Crossland CJ (eds) Mexican and Central American coastal lagoon systems: Carbon, nitrogen and phosphorus fluxes, LOICZ reports \& studies $\mathrm{N}^{\circ} 13$, LOICZ International Project Office, Texel, The Netherlands, pp 9-15

David L, Kjerfve B (1998) Tides and currents in a two-inlet coastal lagoon: Laguna de Terminos, Mexico. Continental Shelf Research, 18:1057-1079

Espinal JC, Salles PAA, Morán DK (2007) Storm Surge and Sediment Process Owing to Hurricane Isidore in Terminos Lagoon, Campeche. In: Kraus NC, Dean Rosati J (eds) Coastal Sediments '07: Proceedings of the Sixth International Symposium on Coastal Engineering and Science of Coastal Sediment Process, American Society of Civil Engineers, Reston, USA, pp 996-1007

Fichez R (2013) El Golfo de México y el mar Caribe: un breve panorama. In: Aldana D, Elias V (eds) Manejo de los recursos pesqueros de la cuenca del Golfo de México y del mar Caribe, Universidad Veracruzana, Veracruz, México, pp 13-19 
Graham DS, Daniels JP, Hill JM, Day JW (1981) a preliminary model of the circulation of Laguna de Términos, Campeche, Mexico. Anales del Instituto de Ciencias del Mar y Limnologia, Universidad Nacional Autonoma de México, 8:51-62

Grenz C, Fichez R, Origel Moreno M, Douillet P, Álvarez Silva C, Calva Benítez L, Conan P, Denis L, Diaz Ruiz S, Gallegos Martinez ME, Ghiglione J-F, Gutiérrez Mendieta FJ, Marquez Garcia AZ, Pujo-Pay M, Torres Alvarado R (2015) A review of current knowledge on Terminos Lagoon (Mexico): a major site for subtropical marine ecosystems ecology studies. Frontiers in Marine Science, in revision.

Hanson RT, Newhouse MW, Dettinger MD (2004) A methodology to assess relations between climatic variability and variations in hydrologic time series in the southwestern United States. Journal of Hydrology, 287:253-270

Hidalgo HG, Amador JA, Alfaro EJ, Quesada B (2013) Hydrological climate change projections for Central America. Journal of Hydrology, 495:94-112

Hirsch RM, Slack JR (1984) A nonparametric trend test for seasonal data with serial dependance. Water Resources Research, 20:727-732

Hudson PF, Hendrickson DA, Benke AC, Varela-Romero A, Rodiles-Hernández R, Minckley WL (2005) Rivers of Mexico. In: Benke AC, Cushing CE (eds) Rivers of North America, Elsevier Academic Press, pp 1030-1084

Kjerfve B, Magill KE, Sneed JE (1988) Modeling of circulation and dispersion in Laguna de Terminos, Campeche, Mexico. In: Yafiez Arancibia A, Day Jr. JW (eds) Ecology of Coastal Ecosystems in the Southern Gulf of Mexico: The Terminos Lagoon Region, Universidad Nacional Autonoma de Mexico, Mexico, pp. 111-129 
Machiwal D, Jha MK (2008) Comparative evaluation of statistical tests for time series analysis: application to hydrological time series. Hydrological Sciences Journal - Journal

Met Office (2011) Climate: observations, projections and impacts. Met Office, Exeter, UK

Mitsch WJ, Hernandez ME (2013) Landscape and climate change threats to wetlands of North and Central America. Aquatic Sciences, 75:133-149

Moberg F, Rönnbäck P (2003) Ecosystem services of the tropical seascape: interactions, substitutions and restoration. Ocean and Coastal Management, 46:27-46

Pavia EG, Graef F, Reyes J (2006) PDO-ENSO Effects in the climate of Mexico. Journal of Climate, 19:6433-643

Putland JN, Mortazavi B, Iverson RL, Wise SW (2014) Phytoplankton Biomass and Composition in a River-Dominated Estuary During Two Summers of Contrasting River Discharge. Estuaries and Coasts, 37:664-679

Ramos Miranda J, Mouillot D, Flores Hernandez D, (2005a) Changes in four complementary facets of fish diversity in a tropical coastal lagoon after 18 years: a functional interpretation. Marine Ecology Progress Series, 304:1-13

Ramos Miranda J, Quiniou L, Flores-Hernandez D, Do Chi T, Ayala Perez L, Sosa Lopez A (2005b) Spatial and temporal changes in the nekton of the Terminos Lagoon, Campeche, Mexico. Journal of Fish Biology, 66:513-530

Robadue D Jr, Oczkowski A, Calderon R, Bach L, Cepeda MF (2004) Characterization of the Region of the Terminos Lagoon: Campeche, Mexico. PlusDraft 1 Site Profile. Draft for discussion. The Nature Conservancy, Corpus Christi, Texas, USA. http://www.crc.uri.edu/download/23s_L1Profile_Draft_Terminos_2004.pdf 
Sáenz-Romero C, Rehfeldt GE, Crookston NL, Duval P, St-Amand R, Beaulieu J, Richardson BA (2010) Spline models of contemporary, 2030, 2060 and 2090 climates for Mexico and their use in understanding climate-change impacts on the vegetation. Climatic Change, $102-595-623$

Sale PF, Agardy T, Ainsworth CH et al. (2014) Transforming management of tropical coastal seas to cope with challenges of the 21st century. Marine Pollution Bulletin, 85:8-23

Sosa López A, Mouillot D, Ramos Miranda J, Flores Hernandez D, Do Chi T (2007) Fish species richness decreases with salinity in tropical coastal lagoons. Journal of Biogeography, 34:52-61

Soto Galera E, Piera J, Lopez, P (2010) Spatial and temporal land cover changes in Terminos Lagoon Reserve, Mexico. Revista de Biologia Tropical, 58:565-575

Thacker WC (2007) Estimating salinity to complement observed temperature: 1. Gulf of Mexico. Journal of Marine Systems, 65:224-248

Valderrama L, Troche C, Rodriguez MT et al. (2014) Evaluation of mangrove cover changes in Mexico during the 1970-2005 period. Wetlands, 34:747-758

Villéger S, Ramos Miranda J, Flores Hernandez D, Mouillot D (2010) Contrasting changes in taxonomic vs functional diversity of tropical fish assemblages after habitat degradation. Ecological Applications, 20:1512-1522

Yáñez-Arancibia A, Lara-Domíguez AL, Chavance P, Hernández DF (1983) Environmental Behavior of Terminos Lagoon Ecological System, Campeche, Mexico. Anales del Instituto de Ciencias del Mar y Limnologia, Universidad Nacional Autonoma de Mexico, 10:137176 
Figure 1

Click here to download high resolution image

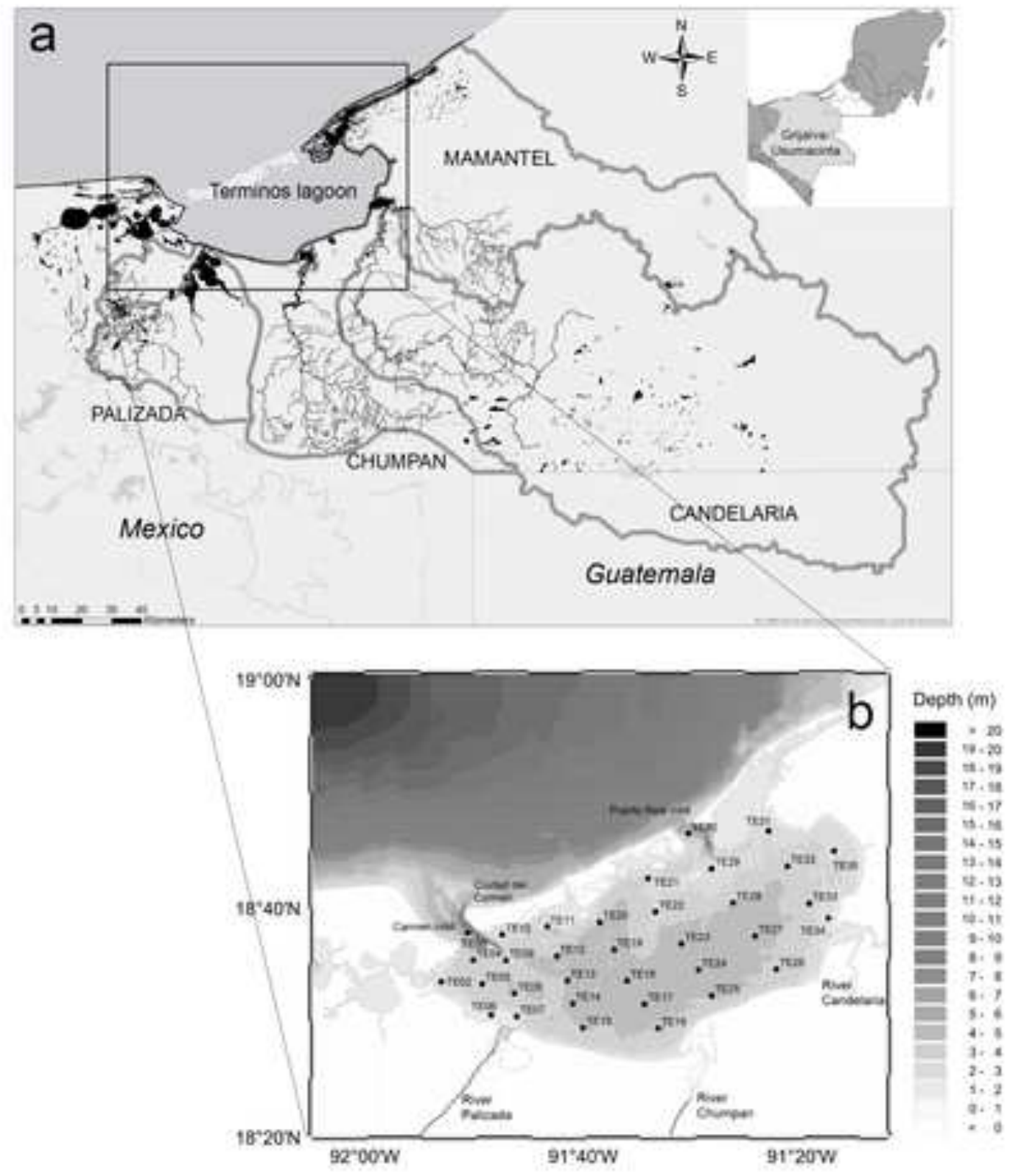



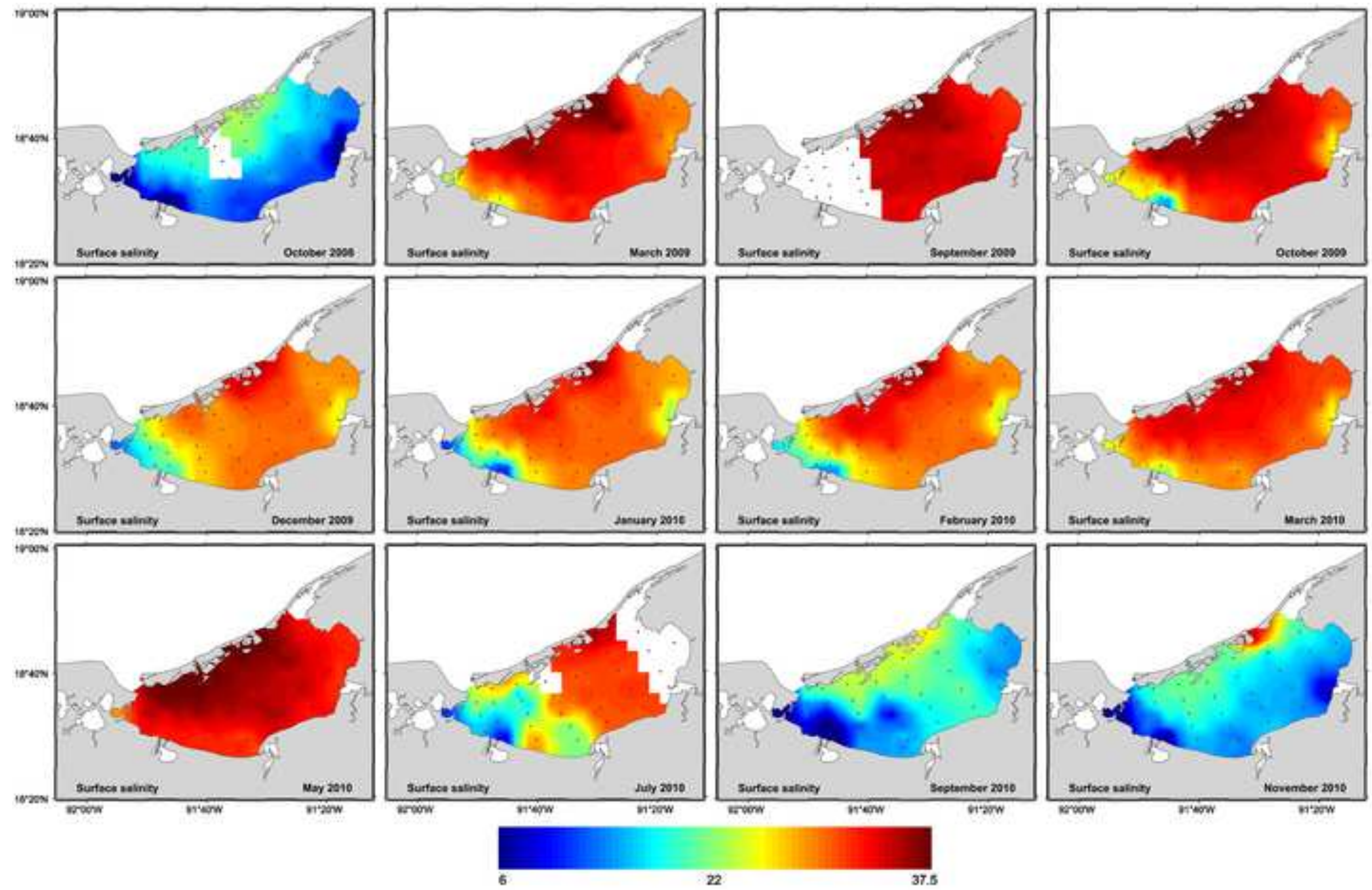


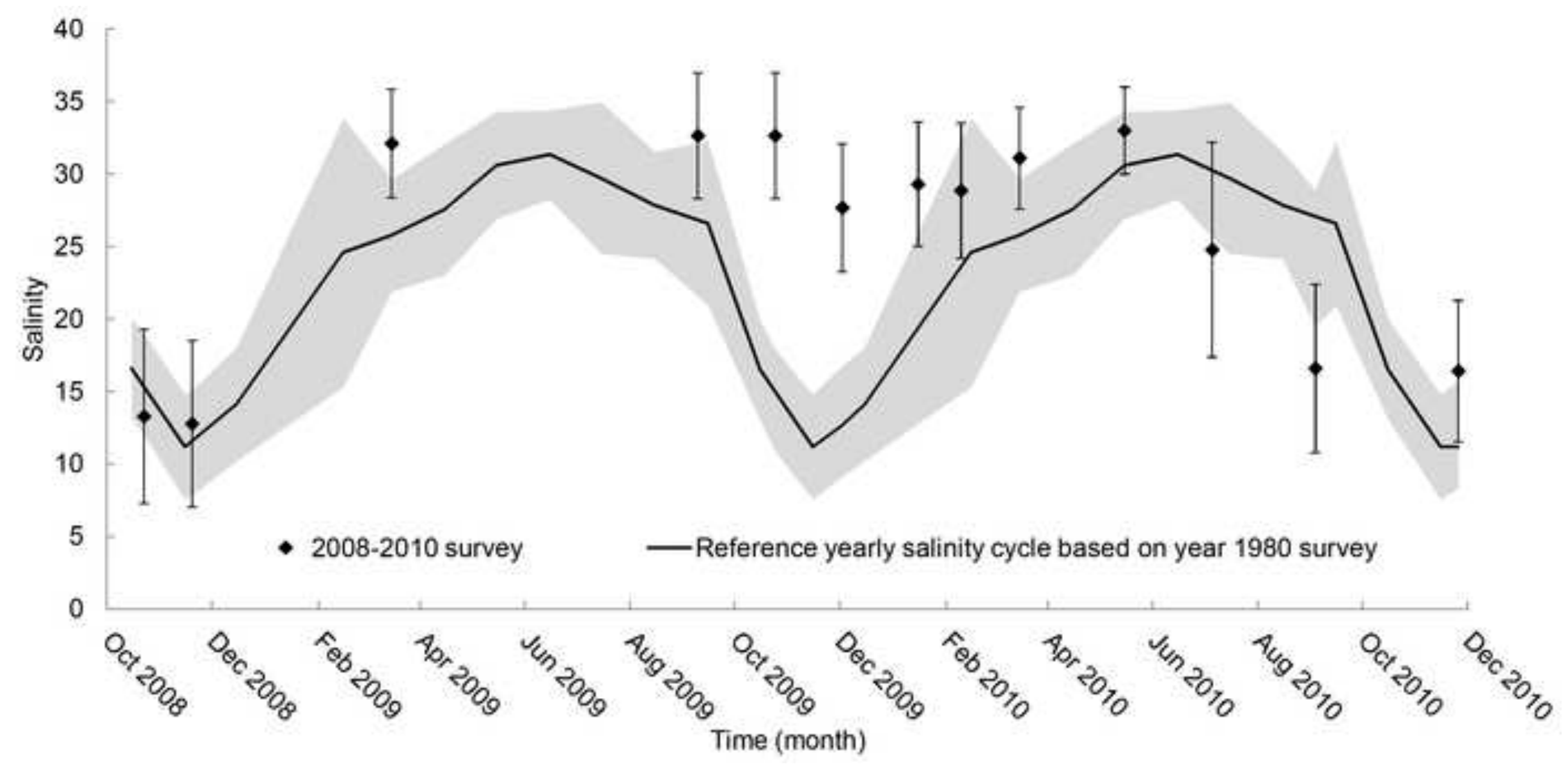




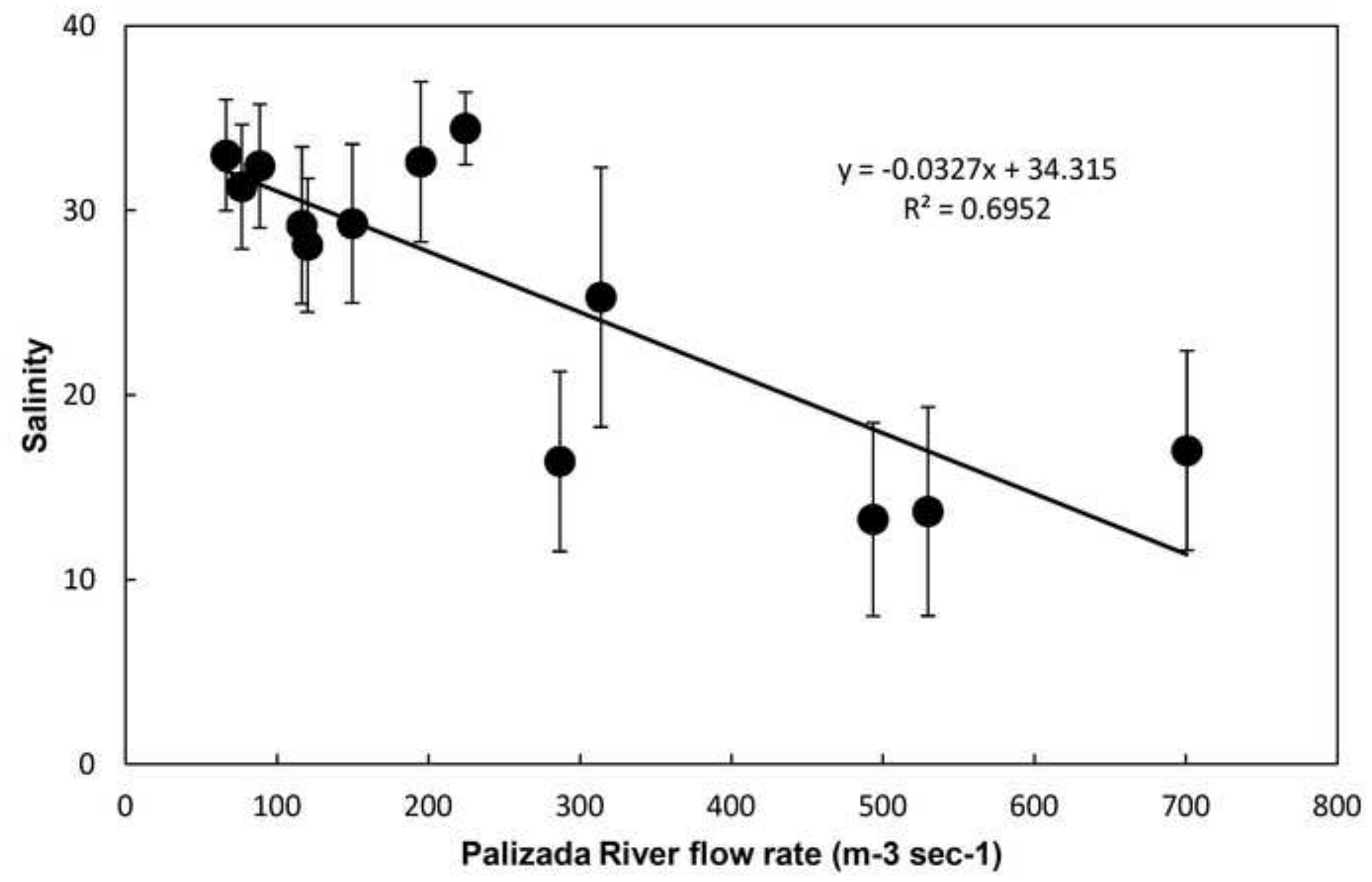




\section{Figure 5}

Click here to download high resolution image
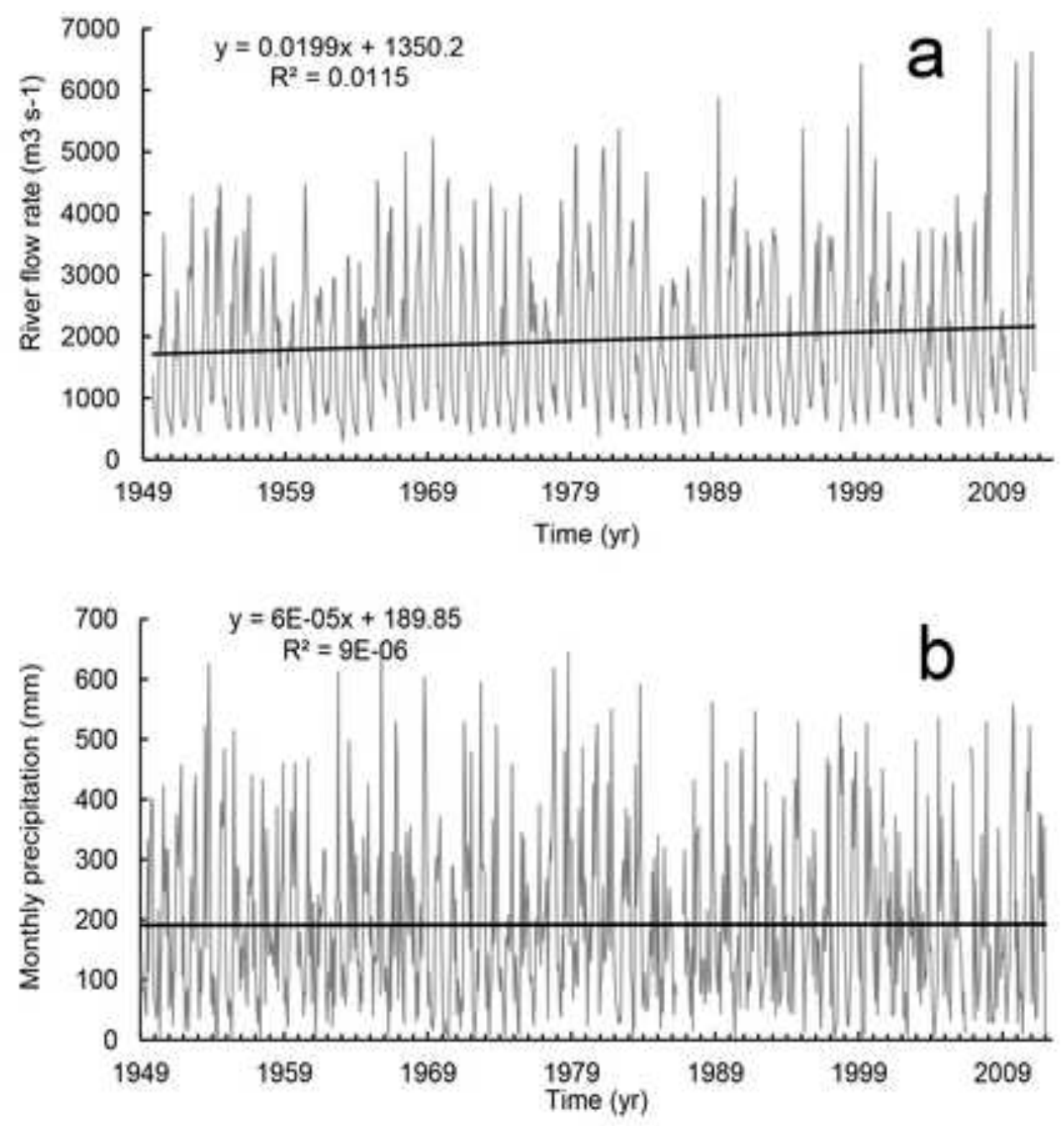


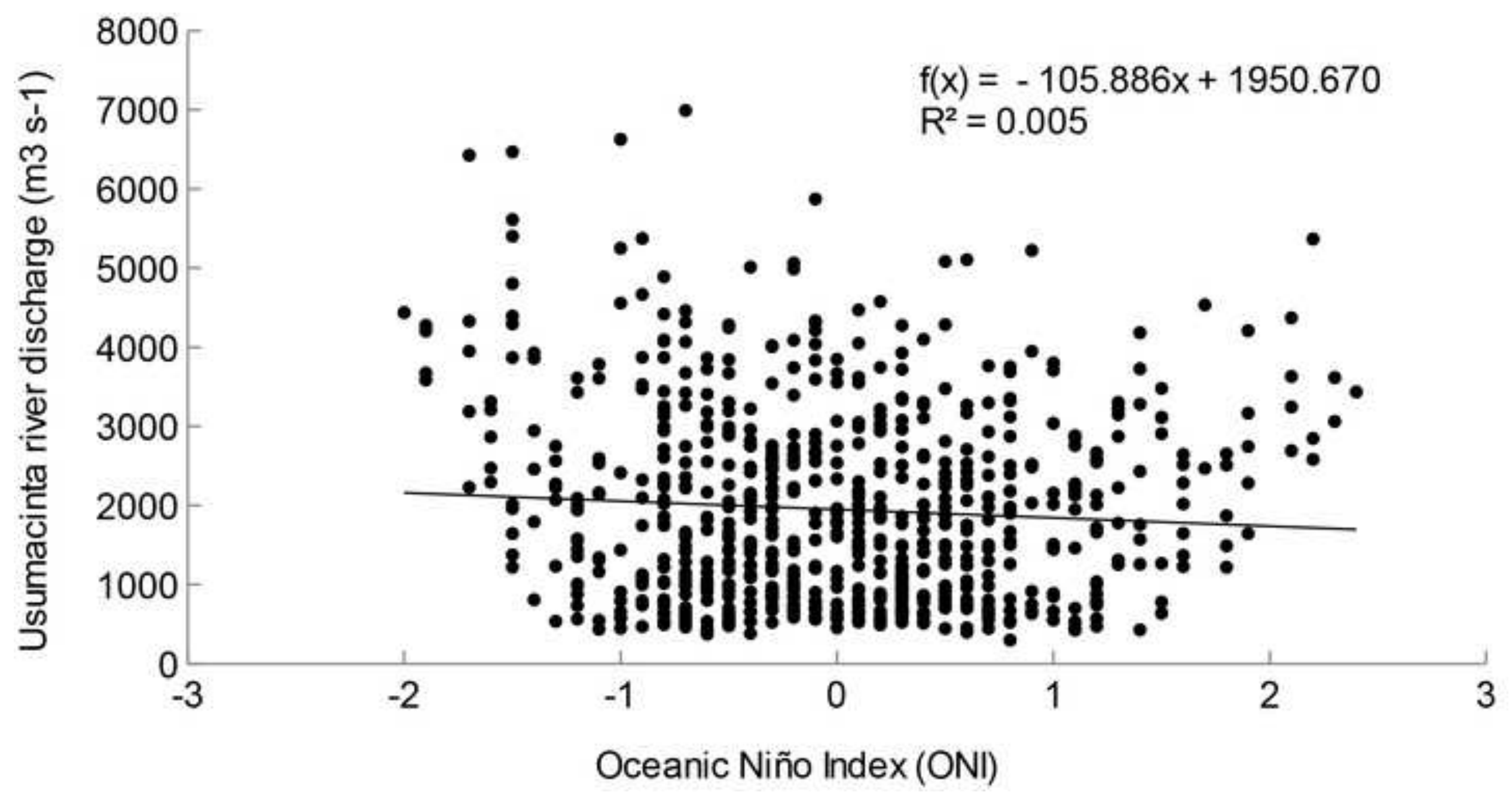

